\title{
Potential Impacts of PCBs on Sediment Microbiomes in a Tropical Marine Environment
}

\author{
James S. Klaus ${ }^{1}$, Vassiliki H. Kourafalou ${ }^{2}$, Alan M. Piggot ${ }^{3}$, Ad Reniers ${ }^{4}$, HeeSook Kang ${ }^{2}$, \\ Naresh Kumar ${ }^{5}$, Elsayed M. Zahran ${ }^{6}$, Leonidas G. Bachas ${ }^{6}$, Adolfo Fernandez ${ }^{7}$, \\ Piero Gardinali ${ }^{7}$, Michal Toborek ${ }^{8}$, Sylvia Daunert ${ }^{8}$, Sapna Deo ${ }^{8}$ and \\ Helena M. Solo-Gabriele ${ }^{9, *}$
}

1 Department of Geological Sciences, College of Arts and Science, University of Miami, Coral Gables, FL 33146, USA; j.klaus@miami.edu

2 Department of Ocean Sciences, Rosenstiel School for Marine and Atmospheric Science, University of Miami, Miami, FL 33149, USA; v.kourafalou@miami.edu (V.H.K.); h.kang@umiami.edu (H.K.)

3 Department of Marine Geosciences, Rosenstiel School for Marine and Atmospheric Science, University of Miami, Miami, FL 33149, USA; alan@piggot.com

4 Faculty of Civil Engineering and Geosciences, Delft University of Technology, Delft, 2628CN, The Netherlands; A.J.H.M.Reniers@tudelft.nl

5 Department of Public Health Sciences, Miller School of Medicine, University of Miami, Miami, FL 33136, USA; nkumar@med.miami.edu

6 Department of Chemistry, College of Arts and Science, University of Miami, Coral Gables, FL 33146, USA; elsayed.zahran@miami.edu (E.M.Z.); bachas@miami.edu (L.G.B.)

7 Department of Chemistry, Florida International University, Miami, FL 33146, USA; afern012@gmail.com (A.F.); gardinal@fiu.edu (P.G.)

8 Department of Biochemistry and Molecular Biology, Miller School of Medicine, University of Miami, Miami, FL 33136, USA; mtoborek@med.miami.edu (M.T.); sdaunert@med.miami.edu (Sy.D.); sdeo@med.miami.edu (Sa.D.)

9 Department of Civil, Architectural, and Environmental Engineering, College of Engineering, University of Miami, Coral Gables, FL 33146, USA

* Correspondence: hmsolo@miami.edu; Tel.: +1-305-284-2908

Academic Editor: Jose Victor Lopez

Received: 8 December 2015; Accepted: 29 January 2016; Published: 22 February 2016

\begin{abstract}
Within the tropical marine study site of Guánica Bay, Puerto Rico, polychlorinated biphenyls (PCBs) are subjected to coastal and oceanic currents coupled with marine microbial and geochemical processes. To evaluate these processes a hydrodynamic model was developed to simulate the transport of PCBs within nearshore and offshore marine areas of Guánica Bay. Material transport and circulation information from the model were matched with measurements from samples collected from within the bay. These samples, consisting of both intertidal and submerged sediments, were analyzed for physical characteristics (organic carbon, grain size, and mineralogy), microbial characteristics (target bacteria levels and microbial community analyses), presence of PCBs, and PCB-degrading enzymes. Results show that the bay geometry and bathymetry limit the mixing of the extremely high levels of PCBs observed in the eastern portion of the bay. Bay bottom sediments showed the highest levels of PCBs and these sediments were characterized by high organic carbon content and finer grain size. Detectable levels of PCBs were also observed within sediments found along the shore. Microbes from the bay bottom sediments showed a greater relative abundance of microbes from the Chloroflexi, phylum with close phylogenetic associations with known anaerobic PCB-degrading organisms. Based on quantitative PCR measurement of the biphenyl dioxygenase gene, the intertidal sediments showed the greatest potential for aerobic PCB degradation. These results elucidate particular mechanisms of PCB's fate and transport in coastal, tropical marine environments.
\end{abstract}


Keywords: polychlorinated biphenyls; PCBs; hydrodynamics; transport; marine sediments; microbiome

\section{Introduction}

Polychlorinated biphenyls (PCBs) are toxic to humans and are believed to constitute health hazards [1]. Although banned from manufacturing in the U.S. [2] and other countries, adverse impacts from PCBs are observed throughout the world because of their widespread use in transformers and long-term persistence [3,4]. The long-term persistence is of particular concern, because exposure to PCBs can lead to bioaccumulation in humans and animals. Many sites throughout the U.S. are under considerable scrutiny for PCB contamination. The majority of these sites, under the U.S. Superfund program which is responsible for remediating some of the nation's most contaminated sites, are on land or river systems. Few PCB contaminated sites are observed in marine systems [5-10]. In these environments, we anticipate unique coastal hydrodynamics, chemical transformations, and microbial responses, which in turn result in unique microbiomes within sediments and on marine flora.

Coastal hydrodynamics are critical because contaminated waste sites in many cases are found close to shore. With the proximity to shore, transport would be influenced by the inter-connected nearshore and offshore marine environments that respond differently to changing environmental conditions, and especially to coastal and offshore ocean circulation patterns and winds. These circulation patterns impact sediment distributions with intertidal sediments likely characterized by aerobic conditions as opposed to anaerobic sediments, which are likely found continuously submerged offshore. These differences, fueled by hydrodynamic processes, could impact the microbiomes of marine environmental sediments.

Under anaerobic conditions, PCB congeners with four or more chlorine atoms generally undergo microbial anaerobic reductive dechlorination, whereby PCBs serve as electron acceptors and chlorine on the PCBs is replaced by hydrogen [11-21]. Prior studies [22,23] have documented several additional pathways to dechlorinate PCBs, with lower-chlorinated PCB congeners undergoing co-metabolic aerobic oxidation through the biphenyl degradation pathway [24]. This pathway is mediated by biphenyl dioxygenase (BPH) enzymes and involves $\mathrm{O}_{2}$ insertion at adjacent unsubstituted carbons, followed by ring cleavage to form a chlorinated benzoate [25-27].

The objective of this study is to evaluate the influence of marine hydrodynamics on the microbial community characteristics in a marine environment impacted by PCBs. The site chosen for this study is Guánica Bay, located in southwestern Puerto Rico, which has been found to have the second highest levels of PCBs in sediment ever recorded worldwide [28]. Our methodology includes field sampling and numerical modeling of circulation and transport. As a first approach, we have concentrated hydrodynamic modeling efforts on the influence of wind-driven circulation, in the context of the complex topography of the study area. The basic understanding of the hydrodynamics achieved herein was used to assess the observed differences in microbial communities between the anaerobic submerged sediments and the intertidal sediments of the bay, including the analysis of microbial communities and BPH enzymes to assess PCB degradation activity under anaerobic and aerobic conditions, respectively.

\section{Methods}

\subsection{Description of Study Site}

Guánica Bay, located in southwestern Puerto Rico near the towns of Ensenada and Guánica, has been subject to research scrutiny by the National Oceanographic and Atmospheric Administration (NOAA) [29-32] and more recently by Kumar et al. [28] for its PCB distribution. NOAA data show that the PCB concentrations in sediments in Guánica Bay are the highest ( $3860 \mathrm{ng} / \mathrm{g}$ per NOAA) in Puerto 
Rico, which according to the NOAA data puts the Bay above the 85th percentile in the U.S. for PCB levels, with levels comparable to Superfund sites in Georgia [33], S. Carolina [34,35], Hudson River [36], and higher than observed levels in San Francisco, Tampa, and Galveston Bays [37,38]. The congeners of particular concern included, PCB146, PCB194, and PCB199, at concentrations within the seven of the highest 10 values ever measured for those congeners within NOAA's National Status and Trends Program [32]. While the levels documented through NOAA are high, more recent analyses [28] indicate that PCB contamination in the Bay is even higher. Kumar et al. [28] collected samples from the eastern part of the Bay, near the town of Guánica. PCB levels in these samples were as high as 129,000 $\mathrm{ng} / \mathrm{g}$ (i.e., the sum of all congeners), the highest ever documented in the U.S. by almost an order of magnitude (Figure 1).

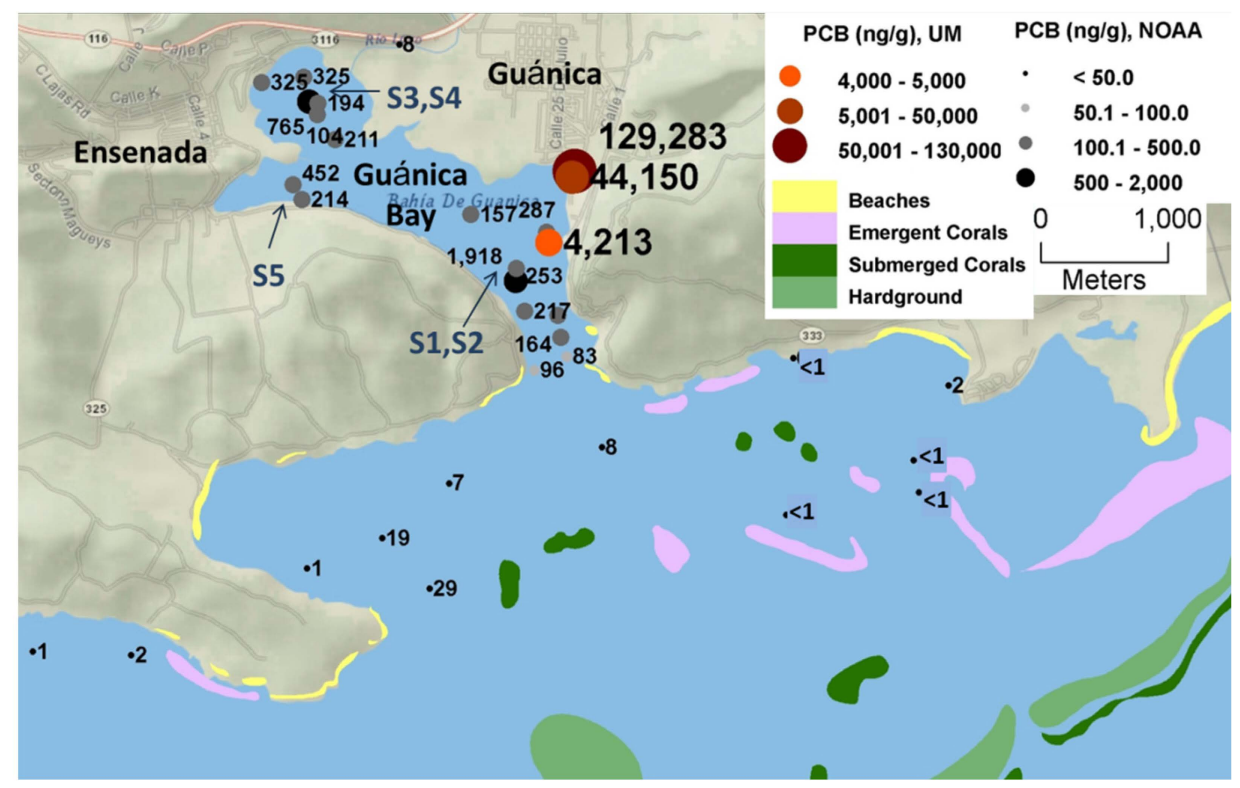

Figure 1. PCB distribution in Guánica Bay. Numbers correspond to PCB concentrations in sediments as documented by NOAA [29,30,32] and Kumar et al. [28]. Arrows represent sampling locations during the Dec. 8, 2012 trip. Yellow areas along the shore correspond to sandy beaches. Reefs are shown in purple (emerged) and dark green (submerged). Light green corresponds to uncolonized hard bottom, which corresponds to areas of coral loss [31]. In the vicinity of the offshore corals, the sediment PCB concentrations are in the single $\mathrm{ng} / \mathrm{g}$ range.

\subsection{Hydrodynamic Modeling}

The focus of the hydrodynamic modeling effort was to evaluate the basic processes controlling transport in Guánica Bay, namely wind-driven circulation and topographic effects. The goal was to first examine if idealized circulation scenarios indicate tendencies for transport of PCB-laden sediments from the hot-spots with highest PCBs to both nearshore and offshore marine environments and to assess wind conditions on PCB retention times within the bay. To evaluate the impacts of wind-driven circulation and topography, we employed the DELFT3D model [39-41] and applied it to a high resolution domain (order of 50-100 m) covering the study area, with detailed topographic data (obtained from NOAA's National Geophysical Data Center). The model has been developed for coastal engineering purposes and is composed of several modules to represent, among other processes, the local hydrodynamics, as well as the transport of heat, salinity and sediments, and concurrent changes in local morphology [39]. These capabilities make DELFT3D a model especially suitable for studying ecological processes and water quality at the coastal scale [42]. In this study, the 3D free-surface model is built on an orthogonal curvilinear grid, with vertical discretization using 10 equidistant sigma layers that follow the bathymetry (Figure 2). The model solves the shallow water equations in 
each vertical layer under the Boussinesq approximation, and is based on the hydrostatic assumption. A Chezy roughness of $55 \mathrm{~m}^{1 / 2} / \mathrm{s}$ was used to represent the bed friction. The vertical eddy viscosity and corresponding diffusivity were calculated with a k-epsilon model [39]. Horizontal turbulent eddy viscosity and associated diffusion were calculated with a parameterization based on Large Eddy Simulations [43].

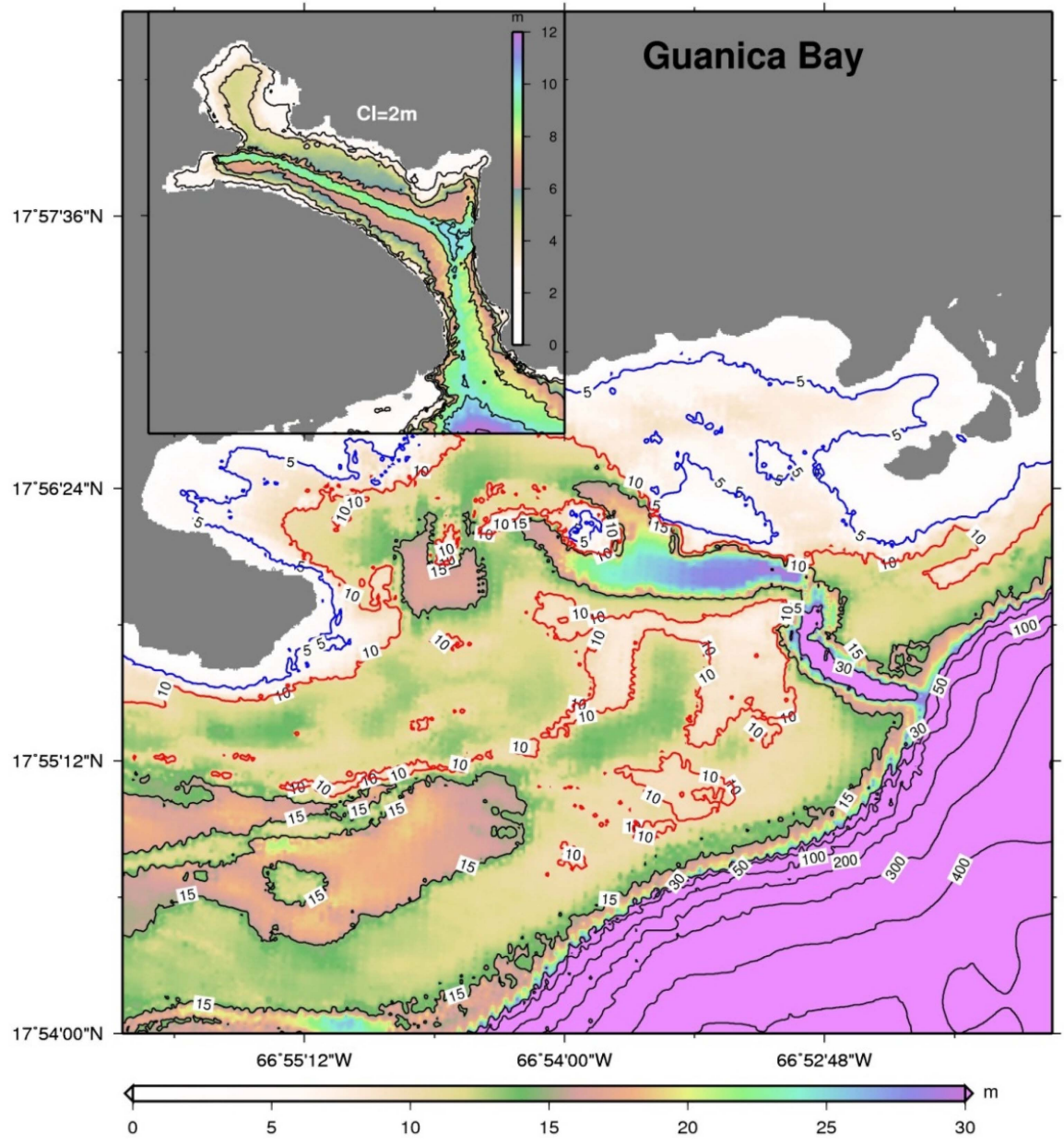

Figure 2. Guánica model domain and bathymetry. Insert marks the shallowest areas and has a different color scale (depths from 0 to $12 \mathrm{~m}$ with a $2 \mathrm{~m}$ increment). Deeper parts have the following depth contour lines: $5 \mathrm{~m}, 10 \mathrm{~m}, 15 \mathrm{~m}, 30 \mathrm{~m}, 50 \mathrm{~m}, 100 \mathrm{~m}, 200 \mathrm{~m}, 300 \mathrm{~m}$ and $400 \mathrm{~m} ; 5 \mathrm{~m}$ contours are marked in blue and $10 \mathrm{~m}$ contours are marked in red to showcase reef areas. Deeper oceanic parts are marked with magenta color and have contours every 100m. Note the deeper channel within the long and narrow channel connecting the shallow embayment at the head of the Guánica Bay (where river runoff is introduced) with the offshore reefs. This channel was artificially dredged for shipping. As illustrated in Figure 1, high levels of PCB are found within this narrow channel and also within the southeast embayment where Kumar et al. [28] identified a second super hot-spot of PCB.

An idealized tracer study (using a simulated and conservative dye) was performed with a total of 6 simulations. Two simulations corresponded to "hot-spots" for PCBs as given by Pait et al. [30]. These hot-spots were located within the northern part of the bay (at sampling location S3) and within the shipping channel located towards the south (at sampling location S1). One corresponded to the location of the intertidal sample (location S5) and another corresponded to the outlet of the river (S6). Even higher PCB contamination was found in the Bay near town of Guánica [28], so the fifth and sixth locations corresponded to the extreme hot-spots located in the far eastern portion of the bay, one at the far end within the eastern embayment (H1) and another closer to the central axis of 
Guánica Bay (H2). For these simulations wind stress was the only circulation forcing mechanism, in the presence of the Earth's rotation (Coriolis force) and topographic effects. The simulated dye was released from the bottom layer at a constant rate of $1 \mathrm{~L} / \mathrm{s}$ with a dye density of $1031 \mathrm{~kg} / \mathrm{m}^{3}$ (the same as seawater). For each site, three 2-day simulations were performed (within the synoptic scale of 5-10 days for atmospheric events) with wind at $10 \mathrm{~m} / \mathrm{s}$ coming from different directions (southerly, easterly, and northerly). Dye was released for 5 days after a one-day spin up of the model simulation. The predominant wind direction in Guánica Bay is easterly (coming from the East), but persistent northerly and southerly directions are also possible.

\subsection{Sample Collection and PCB Analysis}

Samples for this study were collected from Guánica Bay on December 8, 2012 at the locations shown in Figure 1, which followed the NOAA coordinates. Two sediment samples were collected from the deepest parts of the bay referred to herein as the "shipping channel", sites S1 and S3. These samples were collected from a boat which was anchored at the site. The surface sediment was dredged using the anchor and subsequently lifted through the water column. The top $2 \mathrm{~cm}$ of dredged sediment was removed and a $500 \mathrm{~mL}$ wide mouth clear pre-cleaned glass jars were filled with the remaining sediment on the anchor. Another two sediment samples were collected from the shorelines, one sample collected from the intertidal zone within the bay perimeter (S5) and the other collected from the banks of the Rio Loco River, which discharges to the bay (S6). These samples were surface-grab samples. In addition to these four sediment samples, two water samples were collected (S2 and S4, corresponding to sediment locations S1 and S3, respectively). Upon collection, samples were placed in an ice cooler and were flown back to the University of Miami for analysis. Sediment samples were analyzed for physical characteristics including calcium carbonate (acid-soluble fraction), grain size, and percent organics. Calcium carbonate was measured gravimetrically through a traditional dissolution in sulfuric acid [44]. Grain size distribution was determined by standard wet sieving [45]. The percent organics was determined by loss on ignition $\left(550^{\circ} \mathrm{C}\right)$. The water samples were analyzed for bacteria by culture methods only (see below).

The sediments were evaluated qualitatively for individual PCB congener levels. Sediment samples were extracted and processed according to standard protocols (Method 3550C [46]). Sediment samples (S1, S3, S5, and S6) were homogenized and an aliquot ( $200 \mathrm{~g}$ ) was air-dried in oven at $40^{\circ} \mathrm{C}$ for 2 days. The dried sediments were then ground to a fine powder using an acid-washed mortar and pestle. Subsequently, a sample of $40 \mathrm{~g}$ of the ground sediment was transferred to a $60-\mathrm{mL}$ pre-cleaned glass vial with a Teflon-lined silicon cap and the surrogate standards 4,4'-dibromooctofluorobiphenyl (DBOFB), PCB 103, and PCB198 were added to each sample. Then a volume of $50 \mathrm{~mL}$ hexane was added into each vial and the vials were sonicated for $6 \mathrm{~h}$ to enhance extraction. The supernatant was separated from the sediment via centrifugation $(1000 \times g$ for $30 \mathrm{~min})$. Before analysis a sequence of clean-up procedures was performed according to EPA methods to remove various interferences. Briefly, the hexane extract was combined with $5 \mathrm{~mL}$ of concentrated sulfuric acid (3 times) to remove organic matter (Method 3665A). Then, $1 \mathrm{~g}$ of sodium sulfate was added to the hexane phase to remove water and hydrophilic compounds (Method 3550C). The sulfur clean-up was achieved by the copper metal approach (Method 3660B). Finally, the hexane extract was passed through a florisil column (Method 3620C) to remove interfering organic compounds. The eluent was recombined and reconcentrated by using a gentle nitrogen stream to 1-mL for analysis by gas chromatography. Tetrachloro-m-xylene (TCMX) was added at this point to assess the recovery of the surrogate standards. The gas chromatograph (Thermo Trace 1310, Waltham, MA, USA) was fitted with a primary capillary column: J\&W DB-5 (30 m long by $0.25 \mathrm{~mm}$ ID and $0.25 \mu \mathrm{m}$ film thickness) and an electron capture detector (Method 8082A). Results are reported qualitatively in terms of presence of $\mathrm{PCB}$ congeners. 


\subsection{Microbial Analyses}

The four sediment samples and two water samples were analyzed for microbial counts of total bacteria, enterococci, and E. coli. Sediment samples were also analyzed for concentrations of extracellular polymeric secretions (EPS). In brief, bacteria were analyzed for microbial counts by extracting $30 \mathrm{~g}$ in $300 \mathrm{~mL}$ of phosphate buffer saline (PBS) as per method described by Boehm et al. [47]. Dilutions of $0.1,0.3$ and $3 \mathrm{~mL}$ of extract in $100 \mathrm{~mL}$ of PBS were processed by standard membrane filtration techniques using R2A, mEI, and mTEC agar for total, enterococci, and E. coli measures, respectively [48-50]. EPS was extracted from three replicate subsamples of fresh sediment ( $\mathrm{g}$ each) using the method described in Piggot et al. [51]. In brief, each sample was extracted for EPS quantification with a solution containing EDTA followed by centrifugation, ethanol precipitation, and spectrophotometric quantification using a phenol-sulfuric acid method [52].

Sediment samples were also subjected to microbiome determinations using high-throughput $16 \mathrm{~S}$ rRNA sequencing. The FastDNA ${ }^{\circledR}$ SPIN kit for Soil (MP Biomedical, Santa Ana, CA, USA) was used to extract genomic DNA from $250 \mathrm{mg}$ sediment samples. Genes encoding for $16 \mathrm{~S}$ rRNA in bacteria were amplified by PCR using a Mastercycler gradient thermocycler (Eppendorf, Wesseling-Berzdorf, Germany). PCR was carried out using primers $8 \mathrm{f}$ 5'-AGAGTTTGATCCTGGCTCAG [53] and 534r 5'-ATTACCGCGGCTGCTGG [54] linked to the 454 Life Sciences (Branford, CT, USA) A and B pyrosequencing adaptor sequences. This primer set targeted the hypervariable regions V1-V3 covering $526 \mathrm{bp}$. PCR was performed using a reaction mixture of $0.2 \mathrm{mM}$ of each dNTP (Promega, Madison, WI, USA), $200 \mathrm{ng}$ each of the forward and reverse primers, $0.5-10 \mu \mathrm{L}$ of the sample preparation, $1 \times \mathrm{Taq}$ Master, $1 \times$ Taq Buffer $\left(50 \mathrm{mM} \mathrm{KCl}, 10 \mathrm{mM}\right.$ Tris- $\mathrm{HCl}$ pH 8.3, $\left.1.5 \mathrm{mM} \mathrm{Mg}(\mathrm{OAc})_{2}\right)$ and water to bring the total volume to $50 \mu \mathrm{L}$. The PCR profile was: one cycle of $4 \mathrm{~min}$ at $94{ }^{\circ} \mathrm{C}, 32$ cycles of $30 \mathrm{~s}$ at $94{ }^{\circ} \mathrm{C}$, $30 \mathrm{~s}$ at $55^{\circ} \mathrm{C}$ and $90 \mathrm{~s}$ at $72{ }^{\circ} \mathrm{C}$, followed by $5 \mathrm{~min}$ at $72{ }^{\circ} \mathrm{C}$. The $526 \mathrm{bp}$ band was excised and purified using the Wizard SV Gel and PCR Clean-Up kit (Promega, Madison, WI, USA). The PCR product was further processed to remove unincorporated primers and nucleotides using the Ampure magnetic bead purification kit in 96-well format (Agencourt, Beverly, MA, USA). SequalPrep kit Normalization plate (96) Kit (Invitrogen, Grand Island, NY, USA) was used to further purify and normalize PCR product concentration when pooling the 18 samples in preparation for pyrosequencing. This product binds approximately the same amount of DNA in each well (25 ng) when DNA is present in excess $(\geqslant 250 \mathrm{ng}$ recommended). The DNA was normalized per the manufacturer's instructions. The pools were constructed by adding an equal volume of each amplicon (after normalization) to a single tube for a final concentration $\sim 1 \mu \mathrm{g} / \mu \mathrm{L}$. The amplicons were sequenced using a 454 GS-FLX pyrosequencer platform (Roche, Mannheim, Germany) with titanium chemistry.

The generated 16S rRNA gene datasets were processed and analyzed using the macQIIME v.1.4 software package [55]. The split_libraries.py script was applied first to separate the libraries and rename the files. Operational taxonomic unit (OTU) determination was performed with the UCLUST algorithm [56] at a genetic divergence level of 3\%, which represents species-level according to Schloss and Handelsman [57]. For this purpose, the most abundant sequence within an OTU was picked by employing the QIIME scripts pick_otus.py and pick_rep_set.py [55]. Taxonomic classification of the picked reference sequences (OTUs) was performed by similarity searches using BLAST (blastall version 2.2.18) [58] against the SILVA SSU database release 111 (SSURef_111_NR_tax_silva_trunc.fasta) [59]. The SILVA taxonomy of the first hit based on E-value was then adopted to infer taxonomy of the representative sequences according to the QIIME script assign_taxonomy.py. An OTU table was created using make_otu_table.py. Singletons, chloroplast and extrinsic domain OTUs were removed from the table by employing filter_otu_table.py. Finally, OTUs that exhibited low coverage $(<95 \%)$ to their BLAST hit were designated as "Unclassified". Detrended Correspondence Analysis (DCA) plots were used to visually depict the differences in the bacterial libraries.

Primer sets specific for the biphenyl dioxygenase gene were used for the quantitative (real-time) PCR (qPCR) assay [60]. qPCR amplification was performed in a volume of $25 \mu \mathrm{L}$ containing: $12.5 \mu \mathrm{L}$ of the DyNAmo HS SYBR Green qPCR Kit (Finnzymes Oy, Espoo, Finland), $0.2 \mathrm{mM}$ each primer, 
$0.2 \mathrm{ng} / \mu \mathrm{L}$ Bovine Serum Albumin, and $10 \mu \mathrm{L}$ of the 1:10 diluted DNA templates. Thermal cycling was preformed using an Eppendorf Realplex4 (Wesseling-Berzdorf, Germany) with the following parameters: $95{ }^{\circ} \mathrm{C}$ initial hold for $15 \mathrm{~min}$ to activate the Taq polymerase, followed by 50 cycles of amplification, with each cycle consisting of denaturation at $94{ }^{\circ} \mathrm{C}$ for $10 \mathrm{~s}$, followed by $20 \mathrm{~s}$ of annealing at $57^{\circ} \mathrm{C}$, followed by an extension step of $30 \mathrm{~s}$ at $72{ }^{\circ} \mathrm{C}$. Fluorescence was measured at the end of each amplification cycle for $20 \mathrm{~s}$ at $82{ }^{\circ} \mathrm{C}$. To verify the results, each quantification was repeated three times at the same concentrations of all chemicals and templates. While it is possible to normalize the BPH copy number to the DNA concentration in the sample, we have chosen to instead normalize this to grams of sediment sample. We did this by maintaining a standard protocol for DNA extraction from the sediment $(0.25 \mathrm{~g}$ of sediment/extraction) and the volume of template eluate added to the qPCR reaction $(1 \mu \mathrm{L})$. As such we are reporting the BPH qPCR results as copy \#/g of sediment. While this is undoubtedly a minimum estimate of the true numbers, we do feel that it is the best way to assess the relative abundance of the $\mathrm{BPH}$ gene amongst these environments.

\section{Results}

\subsection{Hydrodynamic Modeling}

The main transport pathways were variable (Figure 3) for a passive dye under the circulation induced by wind and modified by the basin morphology. Winds coming from the North create rapid offshore transport for the dye released closest to the outlet of the bay (S1). Releases at the river outlet (S6) and from the intertidal zone (S5) are also transported southward and remain adjacent to the intertidal zone. The release from the northern embayment within the shipping channel (S3) tends to circulate within this embayment. Releases from the eastern embayment also tend to remain within the bay with more transport towards the outlet of the bay for site $\mathrm{H} 2$ relative to H1. Winds coming from the South cause retention of the dye within the bay with a majority transported towards the northwest. The only exception is site $\mathrm{H} 2$ which shows transport towards the outlet of the bay. Winds from the East (which prevail in this region) result in a net transport towards the East with very little exchange with the open ocean leading to higher concentrations in the bay. The release from the outlet of the river runs adjacent to the northwestern border of the bay. In all cases, releases tend to remain within the bay with the exception of sites closest to the outlet, $\mathrm{S} 1$ and $\mathrm{H} 2$, where transport occurs towards the outlet under northerly and southerly wind conditions. Dye releases from H1, the area characterized by extreme PCB levels, tend to remain contained in the eastern portion of the bay under all wind directions.

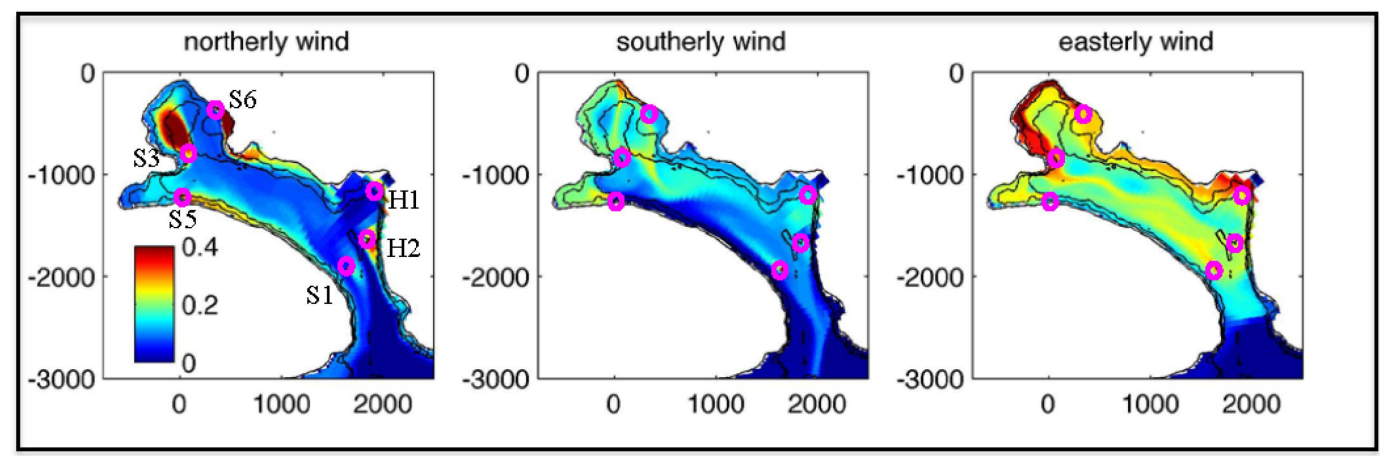

Figure 3. Distribution of dye concentration in the Guánica Bay model simulations with winds coming from North (left), South (middle); and East (right). Coordinates denote distance in meters. Dye concentration (color coded) is in mg/L. The realistic bathymetry shown in Figure 2 has been used. Magenta circles denote the release sites. Sites S1 and S3 correspond to the shipping channel. Site $\mathrm{S} 5$ corresponds to a release from the intertidal zone. S6 corresponds to the river outlet. H1 and H2 correspond to releases from the east embayment where extremely high levels of PCBs were found. 
Given the distribution within the sediments, the source of PCBs in Guánica Bay appears to come from the eastern portion of the bay. Under some wind scenarios these sediments can be dispersed with a net flux outwards towards the ocean. Transport through the outlet of Guánica Bay tends to move towards the West, which is consistent given the direction of the longshore current [32]. Also, consistent with the influence of wind direction on transport within the bay, retention times of the dye varied with wind direction (Figure 4). For all source areas considered, over $90 \%$ of the dye was retained in the bay after five days under easterly wind conditions. Under northerly or southerly wind conditions less was retained (between 50\% and 60\%).

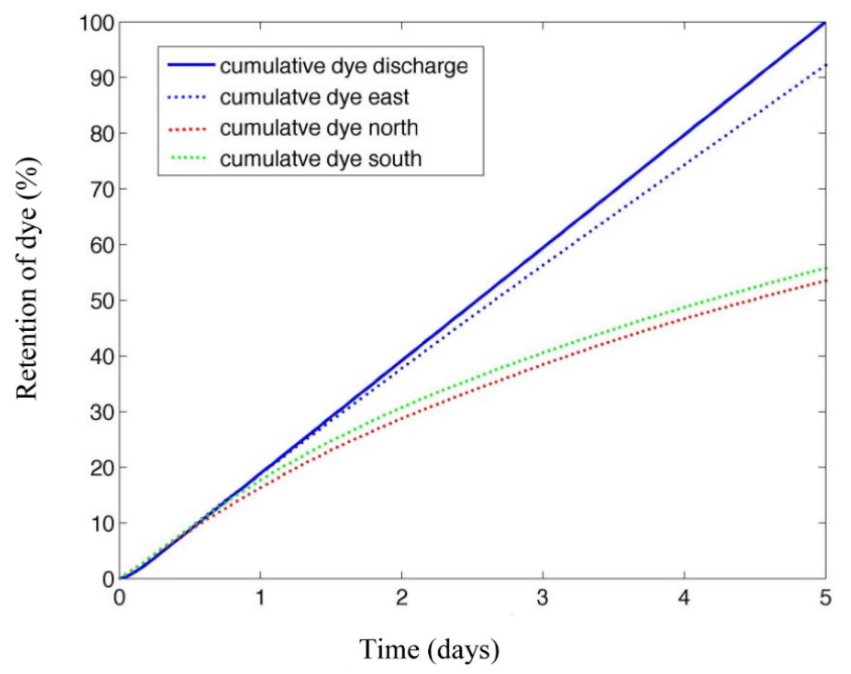

Figure 4. Percent retention of dye versus time under different wind conditions (easterly-blue dotted, northerly-red dotted, and southerly winds-green dotted). Values correspond to average for the dye release locations shown in Figure 3.

\subsection{Sediment Properties and PCBs}

The physical properties of the sediment samples were different depending upon their location (Table 1). Samples S1 and S3, located in the deepest parts of the bay were characterized by higher organic carbon content $(\sim 13 \%)$ whereas samples from the shore and riverbank were characterized by much lower values $(\sim 8.6 \%)$. The proportion of calcium carbonate grains was highest in the shoreline sediments $(\sim 70 \%)$, and these sediments were also the coarsest.

Table 1. Characteristics of Sediments from Guánica Bay.

\begin{tabular}{ccccc}
\hline Sample ID & Organic Carbon (\%) & EPS $(\mu \mathrm{g} / \mathrm{g})$ & $\mathrm{CaCO}_{3}(\%)$ & $\begin{array}{c}\text { Mean Grain Size (Diameter } \\
\text { in } \boldsymbol{\mu m} \text { at Which 50\% Finer) }\end{array}$ \\
\hline S1 Submerged & 13.0 & 20.1 & 39.2 & $<45$ \\
S3 Submerged & 13.3 & 19.6 & 17.9 & $<45$ \\
S5 Shore & 8.6 & 31.4 & 69.6 & 1400 \\
S6 River Bank & 8.7 & 2.5 & 1.0 & 90 \\
\hline
\end{tabular}

PCB chromatographs for the samples collected on 8 December 2012 indicate the presence of congeners consistent with those detected earlier by NOAA [29,30,32]. The relative area and height of the chromatographic peaks were larger for samples S1 and S3, reconfirming the "hot-spot" locations within the bay's shipping channel and lower for the influent river (site S6). Intertidal sediments, within depositional areas as indicated by modeling efforts described above, show intermediate levels. Samples collected from within the bay show 18 specific PCB congeners. A similar range of chromatographic peaks, although smaller, is also observed from intertidal sediments, confirming that the PCBs are 
impacting the intertidal zone where direct exposure to humans is possible. The list of PCB congeners detected (Table 2) was similar among all sites evaluated suggesting a redistribution of a common source of PCBs throughout the bay. S1 and S3 had almost an identical list of congeners detected with the exception of PCB44 which was not detected in S1. S5 was missing several congeners relative to S3. These congeners were either characterized by less than five chlorines (PCB8/5, PCB29, PCB44, PCB66/95) or by eight or nine (PCB195/208). The lack of congeners PCB8/5, PCB29, PCB44, PCB66/95 in S5 in comparison to S3 is consistent with the presence of higher BHP levels in S5 (vide supra); the latter indicates that microbial oxidative processes contribute more significantly in the breakdown of PCB in the coastal sediments in comparison to the submerged sediments. Comparing the congeners detected in the super hot-spot location along the eastern section of the bay shows that the Kumar et al. [28] sample had many more congeners detected (104 relative to 27). These congeners were spread throughout the spectrum of different congener types. However, the Kumar et al. [28] sample included 4 non-ortho substituted PCB congeners that were not observed in the samples collected through the current study. Non-ortho PCBs are generally easier to degrade than ortho PCBs, further suggesting the possibility that some PCBs may be selectively degrading from the source areas on the eastern side of the bay. Another possibility is that the dilution of the sample results in some congeners, including the non-ortho PCBs, to decrease below detection limits.

Table 2. Presence of PCB congeners in submerged sediment samples (S1 and S3) and the intertidal sediment samples (S5). PCB103 and PCB198 are not shown as they were used as internal standards.

\begin{tabular}{|c|c|c|c|c|c|}
\hline \multirow[t]{2}{*}{ PCB Congener } & \multicolumn{4}{|c|}{ Sample ID } & \multirow[t]{2}{*}{ \# Chlorine } \\
\hline & S1 & S3 & S5 & $21 *$ & \\
\hline $1,7 / 9$ & ND & ND & ND & $\sqrt{ }$ & Mono-, Di- \\
\hline $8 / 5$ & $\sqrt{ }$ & $\sqrt{ }$ & ND & $\sqrt{ }$ & Di- \\
\hline $15,16 / 32$ & ND & ND & ND & $\sqrt{ }$ & Di- \\
\hline 18 & $\sqrt{ }$ & $\sqrt{ }$ & $\sqrt{ }$ & $\sqrt{ }$ & Tri- \\
\hline $22 / 51,24 / 27,25,26$ & ND & ND & ND & $\sqrt{ }$ & Tri- \\
\hline 29 & $\sqrt{ }$ & $\sqrt{ }$ & ND & $\sqrt{ }$ & Tri- \\
\hline $28 / 31$ & $\sqrt{ }$ & $\sqrt{ }$ & $\sqrt{ }$ & $\sqrt{ }$ & Tri- \\
\hline $33 / 53 / 20,40,41 / 64,42 / 59 / 37,43$ & ND & ND & ND & $\sqrt{ }$ & Tri-, Tetra- \\
\hline 44 & ND & $\sqrt{ }$ & ND & $\sqrt{ }$ & Tetra- \\
\hline $45,46,47 / 48 / 75,49$ & ND & ND & ND & $\sqrt{ }$ & Tetra- \\
\hline 52 & $\sqrt{ }$ & $\sqrt{ }$ & $\sqrt{ }$ & $\sqrt{ }$ & Tetra- \\
\hline $56 / 60$ & ND & ND & ND & $\sqrt{ }$ & Tetra- \\
\hline $66 / 95$ & $\sqrt{ }$ & $\sqrt{ }$ & ND & $\sqrt{ }$ & Tetra- \\
\hline $70,74 / 61,81$ & ND & ND & ND & $\sqrt{ }$ & Tetra- \\
\hline $82,83,84,85,86$ & ND & ND & ND & $\sqrt{ }$ & Penta- \\
\hline $87 / 115$ & $\sqrt{ }$ & $\sqrt{ }$ & $\sqrt{ }$ & $\sqrt{ }$ & Penta- \\
\hline $88,92,95,97,99$ & ND & ND & ND & $\sqrt{ }$ & Penta- \\
\hline $101 / 90$ & $\sqrt{ }$ & $\sqrt{ }$ & $\sqrt{ }$ & $\sqrt{ }$ & Penta- \\
\hline $105,107,110 / 77,114 / 131 / 122$ & ND & ND & ND & $\sqrt{ }$ & Penta- \\
\hline 118 & $\sqrt{ }$ & $\sqrt{ }$ & $\sqrt{ }$ & $\sqrt{ }$ & Penta- \\
\hline 128 & $\sqrt{ }$ & $\sqrt{ }$ & $\sqrt{ }$ & $\sqrt{ }$ & Penta- \\
\hline $129 / 126,136$ & ND & ND & ND & $\sqrt{ }$ & Hexa- \\
\hline $138 / 160$ & $\sqrt{ }$ & $\sqrt{ }$ & $\sqrt{ }$ & $\sqrt{ }$ & Hexa- \\
\hline $141 / 179,146,149 / 123,151$ & ND & ND & ND & $\sqrt{ }$ & Hexa- \\
\hline $153 / 132$ & $\sqrt{ }$ & $\sqrt{ }$ & $\sqrt{ }$ & $\sqrt{ }$ & Hexa- \\
\hline $156 / 171 / 202,158,166,167,169$ & ND & ND & ND & $\sqrt{ }$ & Hexa- \\
\hline $170 / 190$ & $\sqrt{ }$ & $\sqrt{ }$ & $\sqrt{ }$ & $\sqrt{ }$ & Hepta- \\
\hline $172,174,176 / 137,177,178$ & ND & ND & ND & $\sqrt{ }$ & Hepta- \\
\hline 180 & $\sqrt{ }$ & $\sqrt{ }$ & $\sqrt{ }$ & $\sqrt{ }$ & Hepta- \\
\hline 183,185 & ND & ND & ND & $\sqrt{ }$ & Hepta- \\
\hline 187 & $\sqrt{ }$ & $\sqrt{ }$ & $\sqrt{ }$ & $\sqrt{ }$ & Hepta- \\
\hline $189,191,194$ & ND & ND & ND & $\sqrt{ }$ & Hepta- \\
\hline $195 / 208$ & $\sqrt{ }$ & $\sqrt{ }$ & ND & $\sqrt{ }$ & Octa- \\
\hline 196/203,199,200,201/17/173, 205 & ND & ND & ND & $\sqrt{ }$ & Octa- \\
\hline 206 & $\sqrt{ }$ & $\sqrt{ }$ & $\sqrt{ }$ & $\sqrt{ }$ & Nona- \\
\hline 209 & ND & ND & ND & $\sqrt{ }$ & Deca- \\
\hline
\end{tabular}

$\sqrt{ }=$ detected. ND $=$ Not detected; ${ }^{*}$ Sample number 21 from Kumar et al. [28]. This sample measured at $129,290 \mathrm{ng} / \mathrm{g}$ total PCB. 


\subsection{Sediment Microbiome}

To quantify the number of target bacteria, culture-based methods were used to show the relative levels of total and fecal indicator bacteria. Traditional microbial community analysis provides the distribution of microbes within a given community but does not describe the actual number or level of bacteria in that community. Culture-based results show that levels of bacteria in the water (in colony forming units, $\mathrm{CFU}$ ) were within acceptable ranges for recreational swimming purposes (Figure 5). However, the levels of bacteria in the sediment were 100-fold higher as compared to recreational beaches in other subtropical environments [61], especially for the intertidal sediment (S5) and the riverbank sediment (S6). The intertidal sediment was also characterized by the highest levels of EPS suggesting increased biological activity (Table 1).

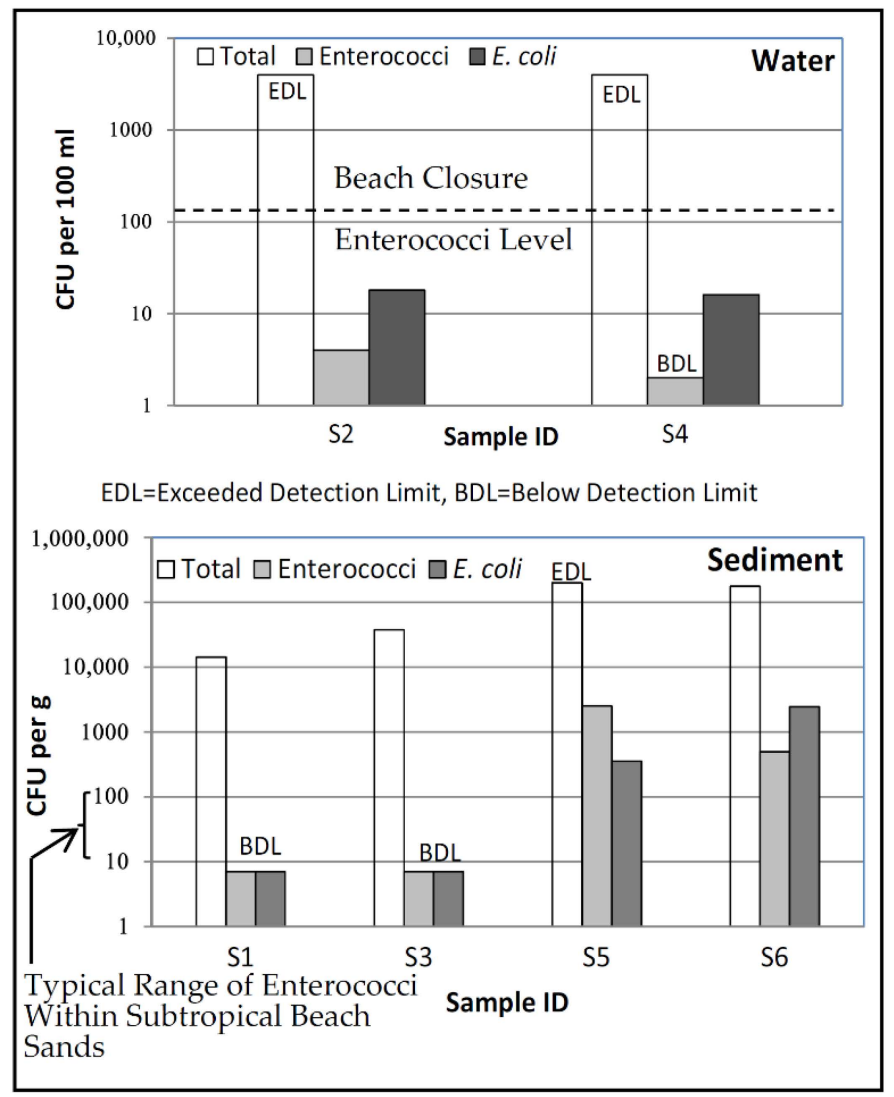

Figure 5. Culturable levels of bacteria from Guánica Bay in water (above) and sediment (below) samples. (EDL = exceeds detection limits).

Results of microbiome analyses suggest a diverse sediment microbiome, with significant variation between sample localities. Pyrosequencing was used to generate a 16S rRNA gene amplicon library of bacterial taxa from four sediment samples of Guánica Bay (S1, S3, S5, S6). A total of 50,800 sequence reads were recovered with a total of 18,174 unique OTUs determined at a genetic distance of $3 \%$. The four libraries ranged in size from a maximum of 34,199 sequences in sample S3, to a minimum of 217 sequences in sample S1. Comparison of observed OTU richness within each sample with the number of OTUs determined by the Chao1 richness estimator revealed that the surveying effort covered between $22 \%$ to $37 \%$ of the estimated taxonomic richness at a $3 \%$ genetic cutoff and $61 \%$ to $70 \%$ at a $5 \%$ genetic cutoff (Figure $6 \mathrm{~A}$ ). Values of the Shannon diversity index ranged from 3.8 to 4.9 (Figure 6B). During the analyses, samples were exposed to differences in sequencing intensity. Despite this uneven intensity, which is undoubtedly not related to PCB concentration, all of the samples display a fairly robust sampling of the community (\% coverage). This provides reassurance that the 
interpretations of the microbial communities are not biased by poor sequencing coverage. The Shannon diversity suggests a lack of large-scale variations in diversity. Overall the percent coverage is acceptable and the Shannon diversity index is probably not influenced by PCB concentration.
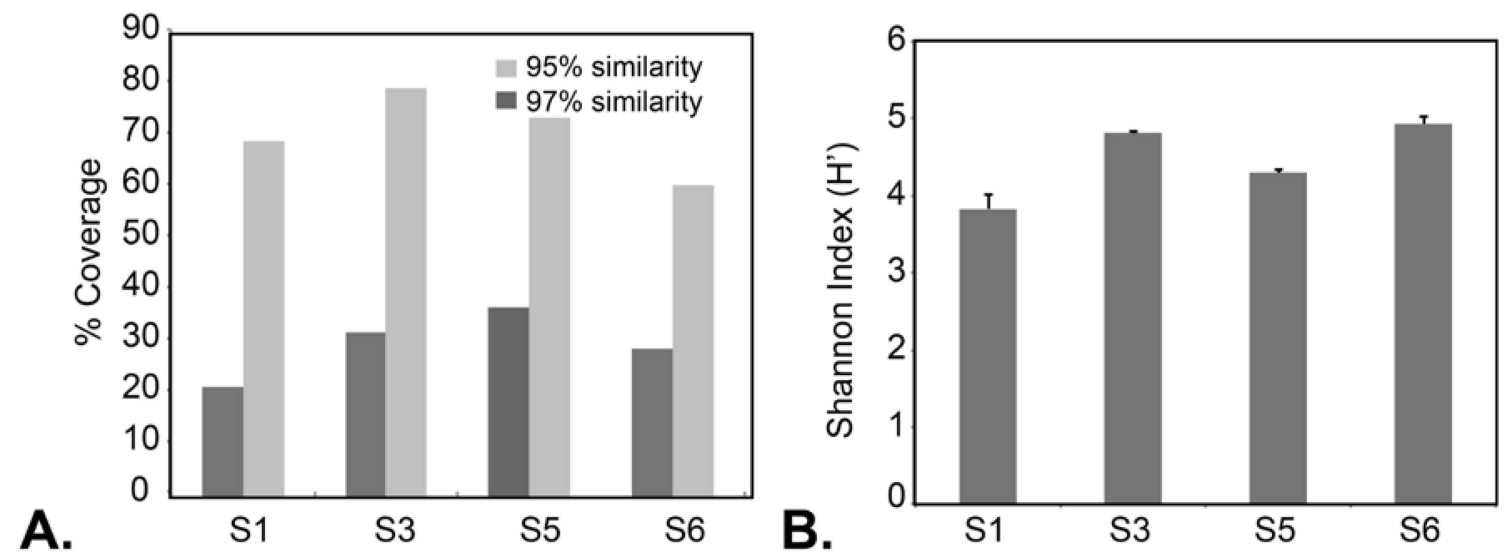

Figure 6. (A) Estimated percent sequencing coverage within each 16S rRNA gene amplicon library based on a 5\% and 3\% genetic cutoff. (B) Bacterial diversity for each 16S rRNA gene amplicon library based on the Shannon Index.

The total relative abundance of OTUs at the phylum level is presented for each library (Figure 7A). The phylum Proteobacteria was subdivided into the classes Alphaproteobacteria, Betaproteobacteria, Deltaproteobacteria, Epsilonproteobacteria and Gammaproteobacteria. Of the 30 different phyla identified from all four sediment libraries, 9 comprised greater than $95 \%$ of the community. Overall, the community was dominated by Firmicutes (12.8\%), Deltaproterobacteria $(12.2 \%)$, Cyanobacteria (including chloroplasts) (10.0\%), Chloroflexi (8.1\%), Bacteroidetes (7.6\%), Gammaproteobacteria (7.4\%), Acidobacteria $(3.6 \%)$, Planctomycetes (3.2\%), Actinobacteria (3.0\%), Alphaproteobacteria (2.5\%), and Lentisphaerae $(2.4 \%)$.

Detrended Correspondence Analysis (DCA) based on the Bray-Curtis similarity index shows the interior bay samples S1 and S3 to be distinct from the shoreline (S5) and river bank (S6) samples (Figure 7B). Samples S1 and S3 showed higher percentages of Deltaproteobacteria (S1 $=27.1 \%, \mathrm{~S} 3=32.9 \%$, $\mathrm{S} 5=5.0 \%, \mathrm{~S} 6=16.6 \%)$ Gammaproteobacteria $(\mathrm{S} 1=21.5 \%, \mathrm{~S} 3=19.2 \%, \mathrm{~S} 5=7.1 \%, \mathrm{~S} 6=2.4 \%)$ and Actinobacteria (S1 $=4.7 \%, \mathrm{~S} 3=3.5 \% \mathrm{~S} 5=2.0 \%, \mathrm{~S} 6=2.7 \%$ ) in comparison to samples S5 and S6. The most common Deltaproteobacteria included the genera Desulfonema, Anaeromyxobacter, and Desulfofustis, while the most common Gammaproteobacteria included Thiohalum and Thioprofundum. Sample S5, from the shoreline, was distinguished from the other samples by a greater abundance of Cyanobacteria $(\mathrm{S} 1=0.6 \%, \mathrm{~S} 3=0.8 \% \mathrm{~S} 5=27.2 \%, \mathrm{~S} 6=2.5 \%)$, Firmicutes $(\mathrm{S} 1=3.5 \%, \mathrm{~S} 3=8.6 \% \mathrm{~S} 5=21.0 \%, \mathrm{~S} 6=5.6 \%)$, and Alphaproteobacteria ( $\mathrm{S} 1=8.9 \%, \mathrm{~S} 3=3.5 \% \mathrm{~S} 5=12.4 \%, \mathrm{~S} 6=7.3 \%$ ). Sample S5 was also distinguished by the lowest percentages of Chloroflexi ( $\mathrm{S} 1=12.4 \%, \mathrm{~S} 3=12.1 \% \mathrm{~S} 5=0.6 \%, \mathrm{~S} 6=10.0 \%$ ) and Acidobacteria $(\mathrm{S} 1=5.3 \%, \mathrm{~S} 3=5.1 \% \mathrm{~S} 5=0.5 \%, \mathrm{~S} 6=6.6 \%$ ). Common genera of the Chloroflexi included Dehalogenimonas, Anaerolinea, Bellilinea and Levilinea. While sample S6 from the Rio Loco River bank is generally similar to samples S1 and S3 at higher taxonomic levels, it can be most easily distinguished by a greater percentage of Betaproteobacteria ( $\mathrm{S} 1=0.0 \%, \mathrm{~S} 3=0.3 \%, \mathrm{~S} 5=0.3 \%, \mathrm{~S} 6=21.2 \%$ ) and Bacteroidetes $(\mathrm{S} 1=2.4 \%$, $\mathrm{S} 3=5.8 \% \mathrm{~S} 5=10.5 \%$, S6 $=16.8 \%$ ).

Quantification of bacterial biphenyl dioxygenase (BPH) genes in Guánica Bay sediments was determined by real-time PCR. As expected for aerobic PCB degradation, the highest levels of BPH gene were detected in the coastal sample S5 (Figure 8). 

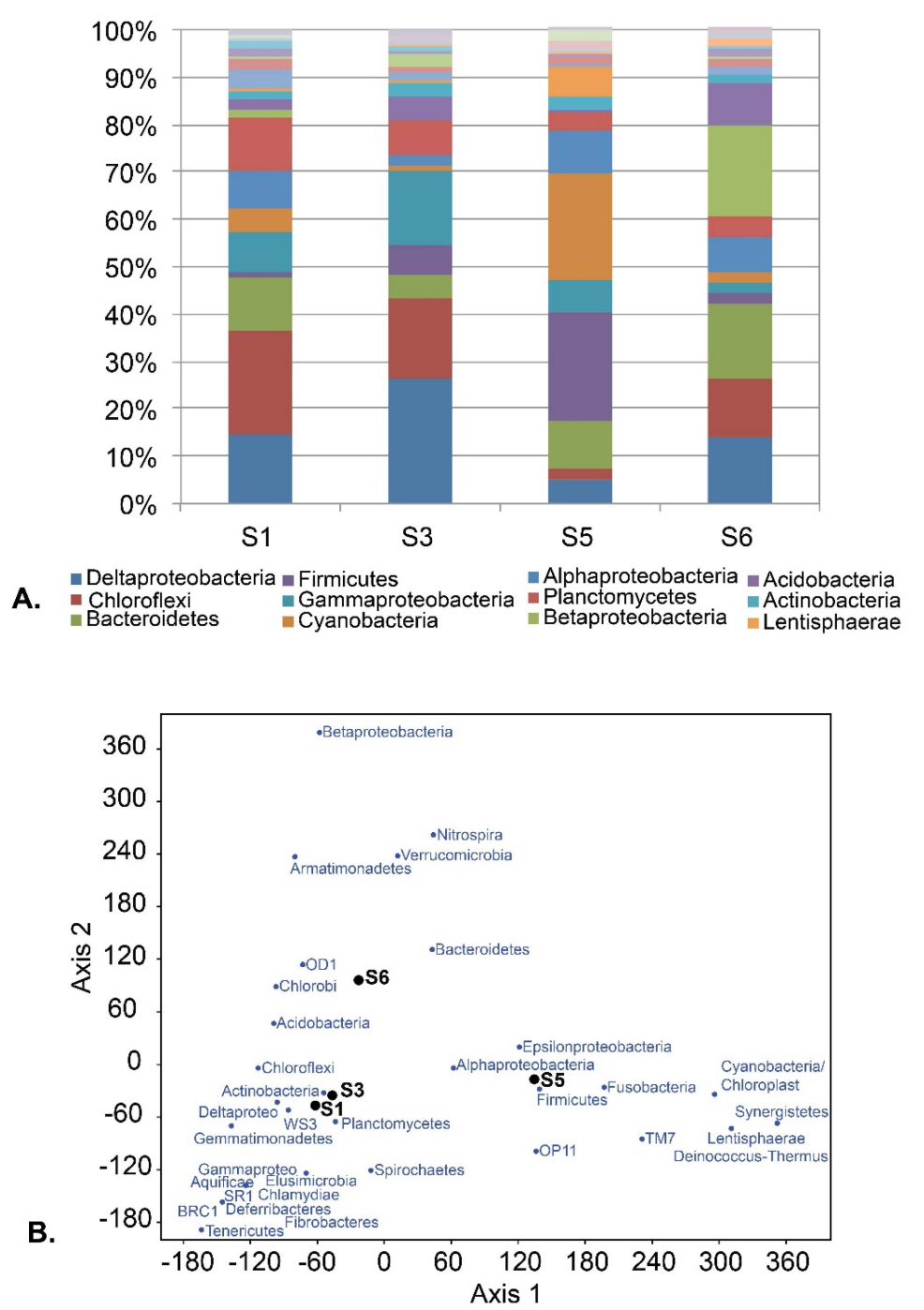

Figure 7. (A) Bar chart illustrating the diversity of bacterial sequences from four Guánica Bay sediment samples based on 454 pyrosequencing. Samples S1 and S3 are characterized by large numbers of Chloroflexi bacteria with affiliations to known PCB degrading strains. Shoreline sediment sample S5 is characterized by increased abundance of Firmicutes and Cyanobacteria. (B) Detrended Correspondence Analysis (DCA) showing the relative similarity of the microbiomes from the four sediment samples and the relative loadings of bacterial phyla.

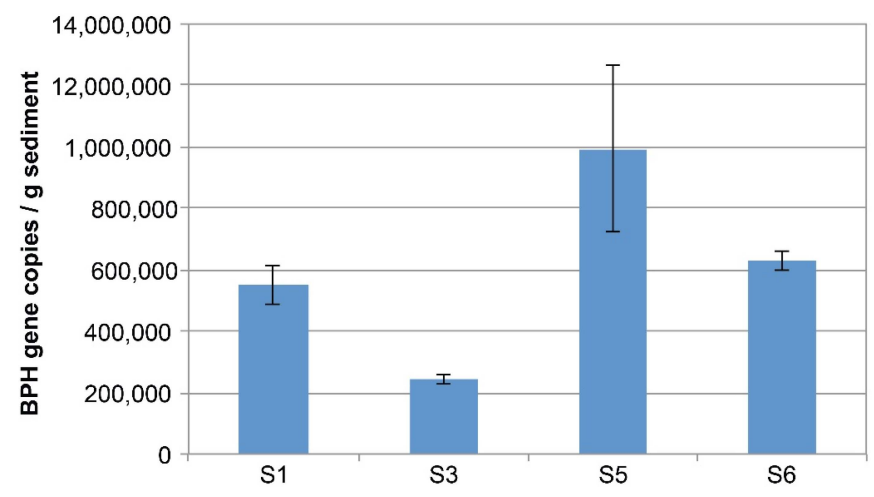

Figure 8. Quantification of bacterial biphenyl dioxygenase (BPH) genes in Guánica Bay sediments as determined by real-time PCR. The highest levels of BPH were detected in the coastal sample S5. 


\section{Discussion}

This study documented the microbial community structure within marine sediments impacted by different levels of PCBs and provided an initial assessment of the hydrodynamic factors that influence the physical, chemical, and microbial characteristics of the sediments. Results showed that the topography of the study area plays an important role in redistribution, mixing and dilution of the PCB sources. The shallow depth and geometry of the eastern part of the bay limits mixing and permits the prolonged retention of the extremely high PCB levels found in this area. Release of PCBs from this area is slower than in other parts of the bay, but ultimately, PCBs are flushed throughout the bay impacting the intertidal sediments. The PCBs along the intertidal zone are particularly concerning given that direct human contact is more common in these areas. Ultimately the PCB laden sediments are transported with a net flux offshore towards the ocean and the offshore reefs, allowing for ecological impacts through potential accumulation in fish [62] and possible impacts to near-shore environments including the coral reefs, which are found immediately offshore [31].

The observed response of the microbial communities to PCBs is consistent with those of other studies that have evaluated microbial communities in PCB-laden soils [63-66] and estuarine sediments [21,67]. This study showed that the higher levels of PCBs in the sediments of Guánica Bay are associated with higher levels of organic carbon and also are associated with finer grained sediments, which is consistent with other studies [68-71]. Samples S1 and S3, collected from the bottom sediments of Guánica Bay are dominated by anaerobic sulfate reducing bacteria (SRB) within the Deltaproteobacteria, as well as members of the Dehalogenimonas genus within the phylum Chloroflexi. Of particular interest, many of the Chloroflexi sequences show affiliation to known anaerobic PCB dechlorinating strains $[66,72]$. The intertidal sediment is also characterized by the highest levels of indicator bacteria and biofilms, suggesting a higher rate of biological activity. Piggot et al. [51] found that EPS, a proxy for biofilm development, in sediments were related to mineralogy. Interestingly, the Guánica Bay shoreline sample with the highest EPS also had the highest level of calcium carbonate. This is consistent with imaging through confocal laser scanning microscopy showing that calcium carbonate grains have a more heterogeneous coating of EPS than do quartz grains [51]. As expected for aerobic PCB degradation, the highest levels of BPH gene were detected in the coastal sample S5 (Figure 8). While the BPH gene was highest in the coastal sample, it is interesting to note that it is still common in the deeper bay sediments (S1, S3) characterized by more anaerobic taxa. Given that these were surface sediment grab samples, it is likely that these BPH genes are associated with bacteria living at the surface-water interface or associated with microenvironments plumbed to the surface through bioturbation. Future studies should assess the distribution of the BPH gene in vertical sediment profiles.

Given these observations, degradation of PCBs is occurring in both surface and submerged sediments through microbially mediated processes. Based upon dechlorination mechanisms documented in the literature [73-76], we hypothesize that lower-chlorinated PCB congeners may be degrading in intertidal sediments and at the sediment-water interface, whereas the higher-chlorinated PCB congeners may be degrading in the submerged anaerobic sediments. Comparison of the congeners between the submerged samples (S1 and S3) and the intertidal sample (S5) suggests a considerable amount of dilution in the intertidal sample augmented perhaps by lower organic content levels, which in turn can be coupled with a history of degradation processes as the PCBs are transported from their source, likely within the eastern embayment. Retention of PCBs within the embayment likely impacts the microbiome of sediments within that area. Future work should include microbial community analysis of samples from this embayed area. The unique hydrologic conditions of this area of very shallow water coupled with extremely high levels of PCBs could elucidate microbial communities that can potentially tolerate extremely high PCB levels under aerobic conditions. 


\section{Conclusions}

By modeling one of the major circulation controlling mechanisms (winds) under a realistic representation of the complex shallow and offshore bathymetry, we were able to identify conditions that promote sediment and PCB retention within the shallow Guánica Bay versus export towards the offshore. The relative levels of PCBs are influenced by the physical characteristics of the sediments (organic content and mineralogy), as well as their microbiological characteristics (biofilm, bacteria levels, and microbial community composition). We found evidence of microbially mediated dechlorination within both the intertidal and submerged sediments. The results of this study can serve as the basis for further model development, expanding the hydrodynamic component presented herein to include the geochemical sediment properties. Ideally a comprehensive modeling tool can be developed. This tool can be potentially applied to determine the preferred PCB transport and degradation pathways through complex, interconnected marine environments under changing hydrodynamic conditions. This information can be ultimately used to evaluate the effects of the PCB redistribution on the microbiomes of marine environmental systems.

Acknowledgments: We thank the many undergraduates who assisted with sample analysis including Athena Jones, Margarita Giraldo, Sarah Johnson, Eric Tazawa, David Hernandez, Laura Vogel, Yifan Zhang, Olivia Piazza, and Kanita Chonecadeedumrongkul. David Withall of NOAA provided background information about the site. We also acknowledge university internal funding received from the College of Arts and Sciences, which was used towards the microbiome analyses.

Author Contributions: J. Klaus, V. H. Kourafalou, and H.M. Solo-Gabriele conceived the ideas included in this paper and designed the analysis plan. J. Klaus focused on the microbiome measures, V.H. Kourafalou focused on the hydrodynamic analyses, and H.M. Solo-Gabriele focused on the PCB measures and coordinated the contributions from the remaining authors. A. Piggot conducted the EPS analyses and provided support for the microbiome measures. A. Reniers ran the hydrodynamic simulations and contributed towards the interpretation of the results. H. Kang prepared the high-resolution bathymetry needed for model simulation and interfaced this information with the modeling effort. N. Kumar consolidated the available sampling data and interpreted the PCB results and potential human health impacts. E. Zahran and L. Bachas led the sediment extraction for PCB measurement and facilitated the interpretation of the chemical data. A. Fernandez and P. Gardinali designed the GC analysis protocol and facilitated the PCB measures. M. Toborek, S. Daunert, S. Deo were responsible for sample collection. All authors edited the manuscript.

Conflicts of Interest: The authors declare no conflict of interest.

\section{References}

1. Kramer, S.; Hikel, S.M.; Adams, K.; Hinds, D.; Moon, K. Current status of the epidemiologic evidence linking polychlorinated biphenyls and non-hodgkin lymphoma, and the role of immune dysregulation. Environ. Health Perspect. 2012, 120, 1067-1075. [CrossRef] [PubMed]

2. Field, J.A.; Sierra-Alvarez, R. Microbial transformation and degradation of polychlorinated biphenyls. Environ. Pollut. 2008, 155, 1-12. [CrossRef] [PubMed]

3. Abraham, W.R.; Nogales, B.; Golyshin, P.N.; Pieper, D.H.; Timmis, K.N. Polychlorinated biphenyl-degrading microbial communities in soils and sediments. Curr. Opin. Microbiol. 2002, 5, 246-253. [CrossRef]

4. Ohtsubo, Y.; Kudo, T.; Tsuda, M.; Nagata, Y. Strategies for bioremediation of polychlorinated biphenyls. Appl. Microbiol. Biotechnol. 2004, 65, 250-258. [CrossRef] [PubMed]

5. Sayler, G.S.; Thomas, R.; Colwell, R.R. Polychlorinated biphenyl (PCB) degrading bacteria and PCB in estuarine and marine environments. Estuar. Coast. Mar. Sci. 1978, 6, 553-567. [CrossRef]

6. Schladow, S.G.; Thomas, E.; Koseff, J.R. The dynamics of intrusions into a thermohaline stratification. J. Fluid Mech. 1992, 236, 127-165. [CrossRef]

7. Hope, B.; Scatolini, S.; Titus, E.; Cotter, J. Distribution patterns of polychlorinated biphenyl congeners in water, sediment, and biota from Midway Atoll (North Pacific Ocean). Mar. Pollut. Bull. 1997, 34, 548-563. [CrossRef]

8. Denton, G.R.W.; Concepcion, L.P.; Wood, H.R.; Morrison, R.J. Polychlorinated biphenyls (PCBs) in marine organisms from four harbours in Guam. Mar. Pollut. Bull. 2006, 52, 214-238. [CrossRef] [PubMed]

9. Nelson, W.G.; Bergen, B.J. The New Bedford Harbor Superfund site long-term monitoring program (1993-2009). Environ. Monit. Assess. 2012, 184, 7531-7550. [CrossRef] [PubMed] 
10. Gomes, H.I.; Dias-Ferreira, C.; Ribeiro, A.B. Overview of in situ and ex situ remediation technologies for PCB-contaminated soils and sediments and obstacles for full-scale application. Sci. Total Environ. 2013, 445-446, 237-260. [CrossRef] [PubMed]

11. Tiedje, J.M.; Quensen, J.F.; Chee-Sanford, J.; Schimel, J.P.; Boyd, S.A. Microbial reductive dechlorination of PCBs. Biodegradation 1993, 4, 231-240. [CrossRef] [PubMed]

12. Ye, D.Y.; Quensen, J.F.; Tiedje, J.M.; Boyd, S.A. Anaerobic dechlorination of polychlorobiphenyls (Aroclor-1242) by pasteurized and ethanoltreated microorganisms from sediments. Appl. Environ. Microbiol. 1992, 58, 1110-1114. [PubMed]

13. Ye, D.; Quensen, J.M.; Tiedje, J.M.; Boyd, S.A. Evidence for para dechlorination of polychlorobiphenyls by methanogenic bacteria. Appl. Environ. Microbiol. 1995, 61, 2166-2171. [PubMed]

14. Fetzner, S.; Lingens, F. Bacterial dehalogenases: Biochemistry, genetics and biotechnical applications. Microbiol. Rev. 1994, 58, 641-685. [PubMed]

15. Natarajan, M.R.; Wu, W.M.; Nye, L.; Wang, H.; Bhatanagar, L.; Jain, M.K. Dechlorination of polychlorinated biphenyl congeners by an anaerobic microbial consortium. Appl. Microbiol. Biotechnol. 1996, 46, 673-677. [CrossRef]

16. Quensen, J.F.; Tiedje, J.M.; Boyd, S.A. Reductive dechlorination of polychlorinated-biphenyls by anaerobic microorganisms from sediments. Science 1988, 242, 752-754. [CrossRef] [PubMed]

17. Quensen, J.F.; Mousa, M.A.; Boyd, S.A.; Sanderson, J.T.; Froese, K.L.; Giesy, J.P. Reduction of aryl hydrocarbon receptor-mediated activity of polychlorinated biphenyl mixtures due to anaerobic microbial dechlorination. Environ. Toxicol. Chem. 1998, 17, 806-813. [CrossRef]

18. Quensen, J.F.; Boyd, S.A.; Tiedje, J.M. Dechlorination of 4 commercial polychlorinated biphenyl mixtures (Aroclors) by anaerobic microorganisms from sediments. Appl. Environ. Microbiol. 1990, 56, 2360-2369. [PubMed]

19. Chen, I.M.; Chang, F.C.; Hsu, M.F.; Wang, Y.S. Comparisons of PCBs dechlorination occurrences in various contaminated sediments. Chemosphere 2001, 43, 649-654. [CrossRef]

20. Wang, S.; He, J. Phylogenetically distinct bacteria involve extensive dechlorination of Aroclor 1260 in sediment-free cultures. PLoS ONE 2013, 8, e59178. [CrossRef] [PubMed]

21. Zanaroli, G.; Balloi, A.; Negroni, A.; Daffonchio, D.; Young, L.Y.; Fava, F. Characterization of the microbial community from the marine sediment of the Venice lagoon capable of reductive dechlorination of coplanar polychlorinated biphenyls (PCBs). J. Hazard. Mater. 2010, 178, 417-426. [CrossRef] [PubMed]

22. Janssen, D.B.; Pries, F.; van der Ploeg, J.R. Genetics and biochemistry of dehalogenating enzymes. Annu. Rev. Microbiol. 1994, 48, 163-191. [CrossRef] [PubMed]

23. Bedard, D.L.; Quensen, J.F. Microbial reductive dechlorination of polychlorinated biphenyls. In Microbial Transformation and Degradation of Toxic Organic Chemicals; Young, L.Y., Cerniglia, C.E., Eds.; Wiley-Liss: New York, NY, USA, 1995; pp. 127-216.

24. Luo, W.; D'Angelo, E.M.; Coyne, M.S. Organic carbon effects on aerobic polychlorinated biphenyl removal and bacterial community composition in soils and sediments. Chemosphere 2008, 70, 364-373. [CrossRef] [PubMed]

25. Abramowicz, D.A. Aerobic and anaerobic PCB biodegradation in the environment. Environ. Health Perspect. 1995, 103, 97-99. [CrossRef] [PubMed]

26. Wright, M.A.; Knowles, C.J.; Stratford, J.; Jackman, S.A.; Robinson, G.K. The dechlorination and degradation of Aroclor 1242. Int. Biodeterior. Biodegrad. 1996, 38, 61-67. [CrossRef]

27. Furukawa, K.; Fujihara, H. Microbial degradation of polychlorinated biphenyls: Biochemical and molecular features. J. Biosci. Bioeng. 2008, 105, 433-449. [CrossRef] [PubMed]

28. Kumar, N.; Ramirez-Ortiz, D.; Solo-Gabriele, H.M.; Treaster, J.B.; Carrasquillo, O.; Toborek, M.; Deo, S.; Klaus, J.; Bachas, L.G.; Whitall, D.; et al. Environmental PCBs in Guánica Bay, Puerto Rico: Implications for community health. Environ. Sci. Pollut. Res. Int. 2016, 23, 2003-2013. [CrossRef] [PubMed]

29. Pait, A.S.; Whitall, D.R.; Jeffrey, C.F.G.; Caldow, C.; Mason, A.L.; Christensen, J.D.; Monaco, M.E.; Ramirez, J. An Assessment of Chemical Contaminants in the Marine Sediments of Southwest Puerto Rico; NOAA Technical Memorandum NOS NCCOS 52; NCCOS Center for Coastal Monitoring and Assessment Biogeography Branch: Silver Spring, MD, USA, 2007; p. 116. 
30. Pait, A.S.; Whitall, D.R.; Jeffrey, C.F.G.; Caldow, C.; Mason, A.L.; Lauenstein, G.G.; Christensen, J.D. Chemical contamination in southwest Puerto Rico: An assessment of organic contaminants in nearshore sediments. Mar. Pollut. Bull. 2008, 56, 580-606. [CrossRef] [PubMed]

31. Pait, A.S.; Jeffrey, C.F.G.; Caldow, C.; Whitall, D.R.; Hartwell, S.I.; Mason, A.L.; Christensen, J.D. Chemical Contaminants in the Coral Porites astreoides from Southwest Puerto Rico; NCCOS Center for Coastal Monitoring and Assessment Biogeography Branch: Silver Spring, MD, USA, 2009; p. 32.

32. Whitall, D.; Bauer, L.J.; Sherman, C.; Edwards, K.; Mason, A.; Pait, T.; Caldow, C. Baseline Assessment of Guánica Bay, Puerto Rico in Support of Watershed Restoration; NOAA Technical Memorandum NOS NCCOS 176; NCCOS Center for Coastal Monitoring and Assessment Biogeography Branch: Silver Spring, MD, USA, 2013; p. 169.

33. Kannan, K.; Maruya, K.A.; Tanabe, S. Distribution and characterization of polychlorinated biphenyl congeners in soil and sediments from a superfund site contaminated with Aroclor 1268. Environ. Sci. Technol. 1997, 31, 1483-1488. [CrossRef]

34. Brenner, R.C.; Magar, V.S.; Ickes, J.A.; Foote, E.A.; Abbott, J.E.; Bingler, L.S.; Crecelius, E.A. Long-term recovery of PCB-contaminated surface sediments at the Sangamo-Weston/Twelvemile Creek/Lake Hartwell Superfund site. Environ. Sci. Technol. 2004, 38, 2328-2337. [CrossRef] [PubMed]

35. Magar, V.S.; Johnson, G.W.; Brenner, R.C.; Quensen, J.F., III; Foote, E.A.; Durell, G.; Ickes, J.A.; McCarthy, C.P. Long-term recovery of PCB-contaminated sediments at the Lake Hartwell superfund site: PCB dechlorination. 1. End-member characterization. Environ. Sci. Technol. 2005, 39, 3538-3547. [CrossRef] [PubMed]

36. Bopp, R.F.; Chillrud, S.N.; Shuster, E.L.; Simpson, J.; Estabrooks, F.D. Trends in chlorinated hydrocarbon levels in Hudson River basin sediments. Environ. Health Perspect. 1998, 106, 1075-1081. [CrossRef] [PubMed]

37. Santschi, P.H.; Presley, B.J.; Wade, T.L.; Garcia-Romero, B.; Baskaran, M. Historical contamination of PAHs, PCBs, DDTs, and heavy metals in Mississippi River Delta, Galveston Bay and Tampa Bay sediment cores. Mar. Environ. Res. 2001, 52, 51-79. [CrossRef]

38. Venkatesan, M.I.; de Leon, R.P.; van Geen, A.; Luoma, S.N. Chlorinated hydrocarbon pesticides and polychlorinated biphenyls in sediment cores from San Francisco Bay. Mar. Chem. 1999, 64, 85-97. [CrossRef]

39. Lesser, G.; Roelvink, J.; van Kester, J.; Stelling, G. Development and validation of a three-dimensional morphological model. Coast. Eng. 2004, 51, 883-915. [CrossRef]

40. Elias, E.; Gelfenbaum, G.; van Ormondt, M.; Moritz, H.R. Predicting sediment transport patterns at the mouth of the Columbia River. In Coastal Sediments; Wang, P., Rosati, J.D., Roberts, T.M., Eds.; World Scientific Publishing Co. Pte. Ltd.: Singapore, Singapore, 2011; Volume 3, pp. 588-601.

41. Lescinski, J.; van Ormondt, M.; Warrick, J. Beach nourishment with high percentage of fine sediment: A modeling study of the Tijuana fate and transport project, California. In Coastal Sediments; Wang, P., Rosati, J.D., Roberts, T.M., Eds.; World Scientific Publishing Co. Pte. Ltd.: Singapore, Singapore, 2011; Volume 3, pp. 43-56.

42. Rynne, P.F.; Reniers, A.J.H.M.; van de Kreeke, J.; MacMahan, J.H. The effect of tidal exchange on residence time in a coastal embayment. Estuar. Coast. Shelf Sci. 2015. in press. [CrossRef]

43. Uittenbogaard, R.E.; van Vossen, B. Subgrid-scale model for quasi-2D turbulence in shallow water. In Proceedings of the Shallow Flows, Delft, Balkema, Rotterdam, The Netherlands, 16-18 June 2003.

44. Pilkey, O.H.; Morton, R.W.; Luternauer, J. The carbonate fraction of beach and dune sands. Sedimentology 1967, 8, 311-327. [CrossRef]

45. Alekseeva, T.N.; Sval'nov, V.N. The refined wet sieving method for the analysis of fine-graded sediments. Lithol. Miner. Resour. 2005, 40, 564-576. [CrossRef]

46. U.S. Environmental Protection Agency. SW-846, Test Methods for Evaluating Solid Waste, Physical/Chemical Methods; Office of Resource Conservation and Recovery: Washington, DC, USA, 2014. Available online: http://www3.epa.gov/epawaste/hazard/testmethods/sw846/online/index.htm (accessed on 6 February 2016).

47. Boehm, A.B.; Griffith, J.; McGee, C.; Edge, T.A.; Solo-Gabriele, H.M.; Whitman, R.; Cao, Y.; Getrich, M.; Jay, J.A.; Ferguson, D.; et al. Faecal indicator bacteria enumeration in beach sand: A comparison study of extraction methods in medium to coarse sands. J. Appl. Microbiol. 2009, 107, 1740-1750. [CrossRef]

48. American Public Health Association. Standard Methods for the Examination of Water and Wastewater, 22nd ed.; American Public Health Association, Inc.: Washington, DC, USA, 2012. 
49. U.S. Environmental Protection Agency. Method 1600: Enterococci in Water by Membrane Filtration Using Membrane-Enterococcu Indoxyl- $\beta$-D-Glucoside Agar (mEI); US EPA Office of Water: Washington, DC, USA, 2002.

50. U.S. Environmental Protection Agency. Method 1603: Escherichia coli (E. coli) in Water by Membrane Filtration Using Modified Membrane-Thermotolerant Exchericia coli Agar (Modified mTEC); US EPA Office of Water: Washington, DC, USA, 2002.

51. Piggot, A.; Klaus, J.S.; Johnson, S.; Phillips, M.C.; Solo-Gabriele, H.M. Enterococci levels are related to sediment biofilms at recreational beaches in South Florida. Appl. Environ. Microbiol. 2012, 78, 5973-5982. [CrossRef] [PubMed]

52. Perkins, R.G.; Paterson, D.M.; Sun, H.; Watson, J.; Player, M.A. Extracellular polymeric substances: Quantification and use in erosion experiments. Cont. Shelf Res. 2004, 24, 1623-1635. [CrossRef]

53. Schlesinger, J.; Navon-Venezia, S.; Chmelnitsky, I.; Hammer-Münz, O.; Leavitt, A.; Gold, H.S.; Schwaber, M.J.; Carmeli, Y. Extended-spectrum $\beta$-lactamases among Enterobacter isolates obtained in Tel Aviv, Israel. Antimicrob. Agents Chemother. 2005, 45, 1150-1156. [CrossRef] [PubMed]

54. Muyzer, G.; de Waal, E.C.; Uitterlinden, A.G. Profiling of complex microbial populations by denaturing gradient gel electrophoresis analysis of polymerase chain reaction-amplified genes coding for 16S rRNA. Appl. Environ. Microbiol. 1993, 59, 695-700. [PubMed]

55. Caporaso, J.G.; Kuczynski, J.; Stombaugh, J.; Bittinger, K.; Bushman, F.D.; Costello, E.K.; Fierer, N.; Peña, A.G.; Goodrich, J.K.; Gordon, J.I.; et al. QIIME allows analysis of high-throughput community sequencing data. Nat. Methods 2010, 7, 335-336. [CrossRef] [PubMed]

56. Edgar, R.C. Search and clustering orders of magnitude faster than BLAST. Bioinformatics 2010, 26, $2460-2461$. [CrossRef] [PubMed]

57. Schloss, P.D.; Handelsman, J. Introducing DOTUR, a computer program for defining operational taxonomic units and estimating species richness. Appl. Environ. Microbiol. 2005, 71, 1501-1506. [CrossRef] [PubMed]

58. Altschul, S.F.; Gish, W.; Miller, W.; Myers, E.W.; Lipman, D.J. Basic local alignment search tool. J. Mol. Biol. 1990, 215, 403-410. [CrossRef]

59. Pruesse, E.; Quast, C.; Knittel, K.; Fuchs, B.M.; Ludwig, W.; Peplies, J.; Glöckner, F.O. SILVA: A comprehensive online resource for quality checked and aligned ribosomal RNA sequence data compatible with ARB. Nucleic Acids Res. 2007, 35, 7188-7196. [CrossRef] [PubMed]

60. Baldwin, B.R.; Nakatsu, C.H.; Nies, L. Detection and enumeration of aromatic oxygenase genes by multiplex and real-time PCR. Appl. Environ. Microbiol. 2003, 69, 3350-3358. [CrossRef] [PubMed]

61. Phillips, M.C.; Solo-Gabriele, H.M.; Piggot, A.M.; Klaus, J.S.; Zhang, Y. Relationships between sand and water quality at recreational beaches. Water Res. 2011, 45, 6763-6769. [CrossRef] [PubMed]

62. Ramirez-Ortiz, D.; Solo-Gabriele, H.; Toborek, M.; Szapocznik, J.; Robertson, L.; Kumar, N. Community Awareness of PCB Contamination in Guánica Bay, Puerto Rico; Department of Public Health Sciences: Miami, FL, USA, 2015.

63. Capodicasa, S.; Fedi, S.; Carnevali, M.; Caporali, L.; Viti, C.; Fava, F.; Zannoni, D. Terminal-restriction fragment length polymorphism analysis of biphenyl dioxygenase genes from a polychlorinated biphenyl-polluted soil. Res. Microbiol. 2009, 160, 742-750. [CrossRef] [PubMed]

64. Correa, P.A.; Lin, L.; Just, C.L.; Hu, D.; Hornbuckle, K.C.; Schnoor, J.L.; Aken, B.V. The effects of individual PCB congeners on the soil bacterial community structure and the abundance of biphenyl dioxygenase genes. Environ. Int. 2010, 36, 901-906. [CrossRef] [PubMed]

65. Petrić, I.; Brub, D.; Udiković-Kolić, N.; Hršak, D.; Philippot, L.; Martin-Laurent, F. Evidence for shifts in the structure and abundance of the microbial community in a long-term PCB-contaminated soil under bioremediation. J. Hazard. Mater. 2011, 195, 254-260. [CrossRef] [PubMed]

66. Kjellerup, B.V.; Paul, P.; Ghosh, U.; May, H.D.; Sowers, K.R. Spatial distribution of PCB dechlorinating bacteria and activities in contaminated soil. Appl. Environ. Soil Sci. 2012, 27, 1-11. [CrossRef]

67. Ho, C.H.; Liu, S.M. Effect of coplanar PCB concentration on dechlorinating microbial communities and dechlorination in estuarine sediments. Chemosphere 2011, 82, 48-55. [CrossRef] [PubMed]

68. Wiegel, J.; Wu, Q. Microbial reductive dehalogenation of polychlorinated biphenyls. Microb. Ecol. 2000, 32, 1-15. [CrossRef]

69. Bedard, D.L. Polychlorinated biphenyls in aquatic sediments: Environmental fate and outlook for biological treatment. In Dehalogenation: Microbial Processes and Environmental Applications; Haggblom, M.M., Bossert, I.D., Eds.; Kluwer Academic Publishers: Boston, MA, USA, 2003; pp. 443-465. 
70. Bedard, D.L. A case study for microbial biodegradation: Anaerobic bacterial reductive dechlorination of polychlorinated biphenyls—from sediment to defined medium. Annu. Rev. Microbiol. 2008, 62, 253-270. [CrossRef] [PubMed]

71. Martinez, A.; O'Sullivan, C.; Reible, D.; Hornbuckle, K.C. Sediment pore water distribution coefficients of PCB congeners in enriched black carbon sediment. Environ. Pollut. 2013, 182, 357-363. [CrossRef] [PubMed]

72. Kjellerup, B.V.; Sun, X.; Ghosh, U.; May, H.D.; Sowers, K.R. Site-specific microbial communities in three PCB-impacted sediments are associated with in situ dechlorinating activities. Environ. Microbiol. 2008, 10, 1296-1309. [CrossRef] [PubMed]

73. Brown, J.F., Jr.; Wagner, R.E.; Bedard, D.L.; Brennan, M.J.; Carnahan, J.C.; May, R.J.; Tokemire, T.J. PCB transformations in upper Hudson sediments. Northeast. Environ. Sci. 1984, 3, 167-169.

74. Brown, J.F., Jr.; Bedard, D.L.; Brennan, M.J.; Carnahan, J.C.; Feng, H.; Wagner, R.E. Polychlorinated biphenyl dechlorination in aquatic sediments. Science 1987, 236, 709-712. [CrossRef] [PubMed]

75. Brown, J.F., Jr.; Wagner, R.E.; Feng, H.; Bedard, D.L.; Brennan, M.J.; Carnahan, J.C.; May, R.J. Environmental dechlorination of PCBs. Environ. Toxicol. Chem. 1987, 6, 579-593. [CrossRef]

76. Alder, A.C.; Haggblom, M.M.; Oppenhelmer, S.R.; Young, L.Y. Reductive dechlorination of polychlorinated-biphenyls in anaerobic sediments. Environ. Sci. Technol. 1993, 27, 530-538. [CrossRef]

(C) 2016 by the authors; licensee MDPI, Basel, Switzerland. This article is an open access article distributed under the terms and conditions of the Creative Commons by Attribution (CC-BY) license (http://creativecommons.org/licenses/by/4.0/). 